\title{
Gold nanoparticles for cancer radiotherapy: a review
}

\author{
Kaspar Haume ${ }^{1 *}$, Soraia Rosa ${ }^{2}$, Sophie Grellet ${ }^{3}$, Małgorzata A. Śmiałek ${ }^{4}$, Karl T. Butterworth², \\ Andrey V. Solov'yov', Kevin M. Prise ${ }^{2}$, Jon Golding ${ }^{3}$ and Nigel J. Mason ${ }^{1}$
}

*Correspondence: kaspar.haume@open.ac.uk 1 Department of Physical Sciences, The Open University, Walton Hall, Milton Keynes MK7 6AA, UK Full list of author information is available at the end of the article

\begin{abstract}
Radiotherapy is currently used in around $50 \%$ of cancer treatments and relies on the deposition of energy directly into tumour tissue. Although it is generally effective, some of the deposited energy can adversely affect healthy tissue outside the tumour volume, especially in the case of photon radiation (gamma and X-rays). Improved radiotherapy outcomes can be achieved by employing ion beams due to the characteristic energy deposition curve which culminates in a localised, high radiation dose (in form of a Bragg peak). In addition to ion radiotherapy, novel sensitisers, such as nanoparticles, have shown to locally increase the damaging effect of both photon and ion radiation, when both are applied to the tumour area. Amongst the available nanoparticle systems, gold nanoparticles have become particularly popular due to several advantages: biocompatibility, well-established methods for synthesis in a wide range of sizes, and the possibility of coating of their surface with a large number of different molecules to provide partial control of, for example, surface charge or interaction with serum proteins. This gives a full range of options for design parameter combinations, in which the optimal choice is not always clear, partially due to a lack of understanding of many processes that take place upon irradiation of such complicated systems. In this review, we summarise the mechanisms of action of radiation therapy with photons and ions in the presence and absence of nanoparticles, as well as the influence of some of the core and coating design parameters of nanoparticles on their radiosensitisation capabilities.
\end{abstract}

Keywords: Gold nanoparticles, Nanomedicine, Radiosensitisation

\section{Background}

Cancer is one of the leading causes of death worldwide and the number of cancer-diagnosed patients is rapidly increasing, in part due to an ageing population, and is expected to reach 22 million cases in the next two decades (Stewart 2015). Currently, the main therapeutic approaches used to treat cancer are surgery, chemotherapy, and radiotherapy, delivered separately or in various combinations (Sánchez-Santos 2012).

Surgery and radiotherapy are key players for treating primary non-metastasised solid tumours, but for patients with co-morbidities that are unfit for surgery, deep-seated tumours, especially those associated with major blood vessels, or brain tumours, combined chemotherapy approaches are common. 
In chemotherapy, pharmaceutical compounds that exert a cytotoxic effect disrupting mechanisms underpinning the rapid overgrowth of malignant cells are administered (Hanahan 2011; Joiner and van der Kogel 2009; Crawford 2013). Conventional chemotherapy is effective but also well-known for its severe side effects owing to the partially non-selective uptake of the chemotherapeutics both into healthy and cancerous cells in tissues and organs. Significant improvement has been made in recent years with the advent of nanomedicine, which provided an important addition to chemotherapy as a new medicine (Sun et al. 2014; Danhier et al. 2010).

Radiotherapy is a key treatment and is beneficial in the treatment of about $50 \%$ of all cancer patients (Delaney and Barton 2015). Such treatment relies on the deposition of energy (the dose) in tumour cells, typically by irradiation with either high-energy gamma rays or X-rays (photons), or energetic beams of ions, sufficient to damage the cancer cells or their vasculature and thus induce tumour death or nutrient starvation. However, like chemotherapy, photon radiotherapy is non-specific, since a significant dose can be delivered to healthy tissue along the track of the photons, in front and behind the tumour (Greish 2007; Hainfeld et al. 2008).

For radiotherapy, the central pathways to increase the therapeutic index, i.e. the ratio of treatment efficacy to side effects, are reversal of radiation resistance in tumour tissue, enhancement of radioresistance in healthy tissue, increasing radiosensitisation in tumour tissue, and better confinement of the deposited dose to the tumour volume (Kwatra et al. 2013). In this review, we will focus on the latter two pathways through the use of nanoparticles to achieve radiosensitisation and ion beam radiation to achieve a higher, more localised dose. The underpinning research involved in this area is highly multidisciplinary, including such diverse fields as atomic cluster physics, collision studies, materials research, nanoparticle synthesis, analytical chemistry focused on characterisation of the bio-nano interactions between the nanoparticles and the biological environment as well as mechanistic in vitro and in vivo studies. This is all aided by advanced imaging and by computational efforts to model the interactions between ions, biological matter, and nanoparticles.

In this review, we would like to sum up some key findings of the newly developed radiotherapy involving gold nanoparticles and bring up some of the mechanisms discovered and methodologies developed. This interdisciplinary research attracts a lot of attention from various communities, thus providing both experimental and computational insights into investigations from molecular to cellular level.

The review is organised as follows: First we present the principal mechanisms of radiotherapy using both photons and ions. Then the mechanisms of using nanoparticles (NPs) to achieve radiosensitisation is presented followed by the influence of several physicochemical properties of such NPs (size, material, coating, charge) and their impact on toxicity and biodistribution. Finally, the paper will conclude with a brief summary of the field and future challenges.

\section{Conventional radiotherapy}

Principles of radiotherapy

Radiotherapy treatments rely on the deposition of energy along the path of the incident radiation. A series of events occur on different time scales after irradiation of biological 
medium and these can, in general, be referred to as the physical, chemical, and biological stages.

During the physical stage, the photons (or ions) interact with the medium, depositing energy, and either directly damage the cell by ionising fragmentation of the DNA or generate secondary species, such as low energy electrons or radicals, that can further damage DNA. This happens within the sub-femtosecond time scale.

Although damage to other parts of a cell than DNA can also lead to its death [for example, damage to mitochondria (Kobayashi et al. 2010; Pan et al. 2009)], the most widely used proxy for determining the efficacy of radiotherapy is to monitor the amount of DNA strand breaks produced. For in vitro work, using plasmid DNA is especially prevalent (Wyer et al. 2009; Folkard et al. 1993; Śmiałek et al. 2013, 2014).

Several studies have shown that the main pathway of DNA damage, from both X-rays and gamma rays, is through the production of water radicals with ca. $70 \%$ of damage caused by radicals and other reactive species-the most important being $\cdot \mathrm{OH}, \mathrm{NO} \cdot \mathrm{H}$, and $\mathrm{H}_{2} \mathrm{O}_{2}$-and $30 \%$ due to secondary electrons and direct fragmentation of the DNA (Kavanagh et al. 2013; Nikjoo et al. 2001; Emfietzoglou et al. 2005; Kwatra et al. 2013). These highly reactive radicals, particularly $\mathrm{OH}$, can rupture molecular bonds and oxidise DNA or proteins of intracellular structures, such as mitochondria or membranes, which affects the stability of the cell membranes and organelles. In addition to the damage produced by radicals, it has been shown that secondary electrons, produced in ionisation events, can cause DNA strand breaks as well through a process known as dissociative electron attachment (Pan et al. 2003). Secondary electrons can also further increase the radical yield by interacting with the water medium as shown in Fig. 1 . The damage due to secondary species is referred to as the indirect damage and takes place at the chemical stage (times within microseconds after irradiation). And finally, during the biological stage (from microseconds and up), the damaged cells exhibit the consequences of the radiation exposure. If exposed to a sufficiently high radiation dose, with appropriate dose rate and dose fractionation, the cell will die.

The damage caused to DNA by radiation can result in a range of various lesions, including base damage, single strand breaks (SSBs) or, less frequently, double strand

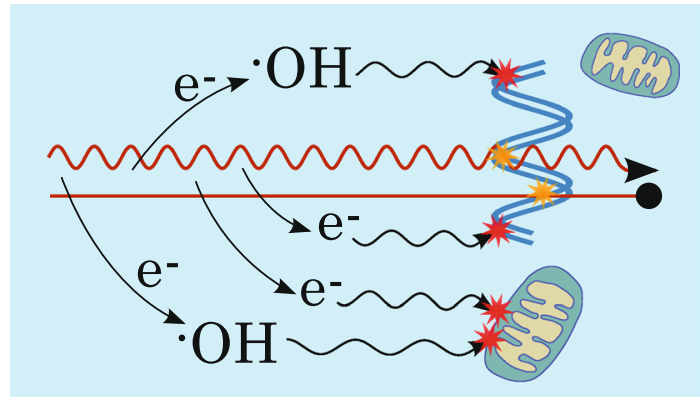

Fig. 1 Illustration of mechanisms of radiation damage. Both photon and ion radiation (red wiggly and straight lines, respectively) may directly damage DNA (marked with yellow stars) or other parts of the cell, such as mitochondria (damage not shown), as well as ionise the medium thereby producing radicals and other reactive species (represented here by the $\cdot \mathrm{OH}$ radical) as well as secondary electrons, which can cause indirect damage after diffusion (red stars). Secondary electrons may also react with the medium to further increase the number of radicals. See text for further details 
breaks (DSBs). In most cases, base damage and SSBs can be effectively repaired by the cell repair mechanisms, whereas DSBs, especially when induced at high levels (often referred to as "clustered" or "complex" damage), are difficult to get successfully repaired and are therefore more damaging to cells (Kobayashi et al. 2010).

The DNA may be successfully repaired ensuring continued, normal cell proliferation and function, or may result in misrepair, which in turn can lead to either its death or to mutations with a possibility of transforming a normal cell into a cancerous cell. Thus increasing the amount of clustered damage as well as sparing healthy tissue is the motivation for seeking a better optimisation of radiation damage during treatment.

Herein, we focus on the external photon and ion beam radiotherapy and their interaction with nanoparticles. The main difference between these two types of radiation lies in their ways of interaction with matter and modalities of the formation of the secondary species.

\section{Photon-based radiotherapy}

In cancer radiotherapy, photons generally refer to either gamma or X-rays, with X-ray energies usually in the range between $80 \mathrm{keV}$ and $25 \mathrm{MeV}$, predominantly in the 8-18 MeV range for modern high-energy linear accelerators that are used to produce and form the radiation beam (Dendy and Heaton 2011). The photons effectively ionise biological matter and due to the relatively simple setup required to produce them, proton-based treatment protocols have been used with great success for decades.

A sufficient dose can kill any tumour cell but the concerns of the amount of damage to healthy tissue in the vicinity of the tumour limit how much radiation a patient can receive (Porcel et al. 2014; Hainfeld et al. 2008). Gamma and X-rays have an exponential dose deposition with tissue depth, therefore a significant fraction of the total dose is delivered to healthy tissue in front of and behind the target (Hainfeld et al. 2008; Krämer and Durante 2010). In an attempt to increase the dose delivered to the target while keeping the dose delivered to surrounding, healthy tissue tolerable, lower-energy radiation from multiple angles can be used. The overlap of the beams on the cancer tissue ensures a high total dose on the target, but invariably leads to a much larger volume of low-doseirradiated healthy tissue (Kobayashi et al. 2010).

An important disadvantage of photon therapy is that cancer tissues can have, or develop, resistance to radiation; moreover, due to the physical extent of this tissue, it can be difficult to effectively irradiate the whole tumour, which may lead to its regeneration (Kwatra et al. 2013).

\section{lon-based radiotherapy}

To overcome the abovementioned disadvantages associated with the photon-based radiotherapy, the therapy based on ions as an alternative method achieved the lowering of the unwanted effects on healthy tissues and better control of the size and shape of the irradiated volume.

Ion radiotherapy refers to the use of ion beams as the radiation source, consisting of ions of hydrogen (protons), helium, carbon, or oxygen. Usually, hydrogen and helium ions are referred to as "light ions" and the others as "heavy ions". 
The attractiveness of ion radiation stems from the characteristic interaction properties with matter, namely that the energy deposition is maximum for low ion velocities. This means that the energy deposition of an ion increases as it traverses tissue, producing radicals and secondary electrons along the track. This causes a strong enhancement of the linear energy transfer (LET, energy deposited per unit distance traversed in units of $\mathrm{keV} / \mu \mathrm{m}$ ) near the end of the track in what is called the Bragg peak (Tsujii et al. 2014). By tuning the incident energy of the ion, the location of the Bragg peak, which extends over only a couple of millimetres, can be directed into the tumour tissue leading to a very high, well-defined, and localised dose. For this reason ion-based therapy is considered superior when tumours are situated close to sensitive tissues or vital organs such as the spinal cord, brain, and eye (Kraft 1990). During therapy, a range of ion energies are delivered, leading to the production of a Spread-Out-Bragg-Peak (SOBP) (Krämer et al. 2000). This increases the volume that can be treated but it also leads to a higher amount of radiation received in the entrance channel (the healthy tissue preceding the target).

The amount of deposited energy depends on the mass and energy of the incident ion, with heavier ions having, in general, a higher LET (Scifoni et al. 2010). However, irradiation with heavier ions tends to deposit some energy beyond the target due to fragmentation of the incident ion near the Bragg Peak. This may produce lighter nuclear fragments which continue depositing some energy, potentially causing further damage to healthy tissue (Haettner et al. 2006).

The prediction of cell killing is not straightforward. When the LET of incident ions increases, the radical production increases as well, which may lead to a reduced number of radicals available to interact with the cell due to recombination of these radicals with each other (Usami et al. 2010; Terato et al. 2008).

\section{Modelling radiation response}

To make predictions of radiation effects, a popular simulation model of the effect of radiotherapy, local effect model (LEM) is used (Elsässer and Scholz 2007; Elsässer et al. 2008). The premise of the LEM is that the local biological response to radiation is equal for equal doses and independent of the type of radiation. If the biological effect of a given dose is known for photon irradiation, then the biological effect of ion radiation can be calculated once the dose is known. The dose can be calculated from the LET of a given ion, which is known from experiments, and can be implemented to the model. The LEM model has shown good agreement with experiments (Krämer and Durante 2010; Elsässer et al. 2008; Combs et al. 2009).

Surdutovich and Solov'yov took another approach and formulated the so-called multiscale approach to the physics of radiation damage with ions (Surdutovich and Solov'yov 2014). In this framework, all physical interactions (e.g. ionisation of matter as well as the production and transport of reactive species such as secondary electrons and free radicals) between ions and matter are accounted for quantitatively, which opens up a possibility to evaluate and predict biological consequences of radiation damage. The multiscale approach combines the information on the production of secondary species, their energy spectra, the transport of secondary species, and the interaction cross sections between electrons and radicals and biological matter. By thorough understanding of these nanoscale processes, one is able to evaluate the probability of single and double 
DNA strand breaks as well as complex DNA lesions to be formed upon irradiation. From these data, survival curves can be obtained as a function of deposited radiation dose (Surdutovich and Solov'yov 2014). In this way, the multiscale approach bridges the femtosecond and sub-nanometre scale up to the biological timescale and dimensions. In a recent publication, the multiscale approach has been proved to successfully predict the survival probability of a number of mammalian cancerous and normal cell lines and some related phenomena, for example oxygen enhancement ratio (Verkhovtsev et al. 2016).

One of the important phenomena predicted and elaborated within the multiscale approach is the thermomechanical pathway of biodamage. It is caused by intense heating of the medium due to relaxation of the energy deposited by projectile ions to the molecules of the medium (Surdutovich and Solov'yov 2010; Surdutovich et al. 2013; de Vera et al. 2016). A rapid increase of temperature and pressure close to the ion's path causes the formation of a shockwave which may damage DNA or other parts of the cell directly and increase the transport of reactive chemical species. Thermomechanical effects were recently shown to be important in the prediction of ion-induced radiation damage thus they need to be accounted for (Verkhovtsev et al. 2016).

\section{Radiotherapy with gold nanoparticles}

In addition to the use of NPs in nanomedicine, which has successfully improved the specificity of modern chemotherapeutics in recent years (Ranganathan et al. 2012; Danhier et al. 2010; Sun et al. 2014), promising demonstrations of the radiosensitising potential of NPs in the last decade, both in vitro and in vivo, now mean that significant research efforts focus on NPs for improved dose localisation for radiotherapy (Hainfeld et al. 2008; Kwatra et al. 2013; Porcel et al. 2012; Liu et al. 2010; Polf 2011).

Gold NPs (AuNPs) in particular, have become popular since they have several advantages, including good biocompatibility, straightforward synthesis in a wide range of sizes, and easy surface functionalisation by the attachment of ligands required to target cancer cells, and organelles therein, or improved life time in the bloodstream (McMahon et al. 2011; Hainfeld et al. 2008; Kwatra et al. 2013; Malam et al. 2009; Barreto et al. 2011; Carter et al. 2007; Liu et al. 2010). Additionally, as discussed later, AuNPs have a large interaction cross section with $\mathrm{X}$-ray radiation up to about $1 \mathrm{MeV}$ as well as with ion radiation.

The contribution of AuNPs in increasing the radiotherapy efficiency is measured by the dose enhancement factor (DEF). The DEF of AuNPs is defined as the ratio of the radiation dose absorbed by the tumour cells in the presence of AuNPs to the dose absorbed in the absence of AuNPs (Muddineti et al. 2015). This may vary with the concentration and characteristics of the AuNPs and their location inside the cell (Butterworth et al. 2012; Hossain 2012).

Among other groups studying the benefit of AuNPs in combination with X-ray radiotherapy, Zhang et al. employed Monte Carlo simulations to show a possible radiosensitisation with AuNPs and found that radiation beam will deposit a lower dose after having passed through the AuNP containing region, thus increasing the therapeutic ratio (Zhang et al. 2009). 
As previously mentioned, the main contribution to the killing of cells from radiotherapy is through the production of free radicals. This is also the source of radiosensitisation when using NPs as they increase the radical production (Porcel et al. 2010; Verkhovtsev et al. 2015a).

The interaction between NPs and radiation is divergent for photons and ions, and will be briefly reviewed below.

\section{Nanoparticles with photon radiation}

$\mathrm{X}$-rays and gamma rays interact with NPs mainly through the excitation and scattering of electrons of the NP (Hainfeld et al. 2008; Kobayashi et al. 2010). When the excited electron comes from an inner shell, the so-called Auger de-excitation processes are especially likely. This leads to one or more Auger electrons being emitted, the latter known as Auger cascades where more than 10 electrons can be emitted (Sancey et al. 2014; Porcel et al. 2010).

Auger electrons have energies below $5 \mathrm{keV}$ and have been shown to be effective in damaging DNA directly in addition to ionising surrounding water molecules (Pan et al. 2003; Butterworth et al. 2013). All of the secondary electrons from the NPs may also interact with other NPs, resulting in further Auger electron emission (Kobayashi et al. 2010; Porcel et al. 2010) or they may be absorbed by the medium causing ionisation and radical formation (Hainfeld et al. 2008), see illustration in Fig. 2. Additionally, Porcel et al. suggested that the positively charged NPs (after emission of photo- or Auger electrons) could cause surrounding water molecules to become unstable and more easily dissociate, further increasing the radical yield in the environment of the NPs (Porcel et al. 2010).

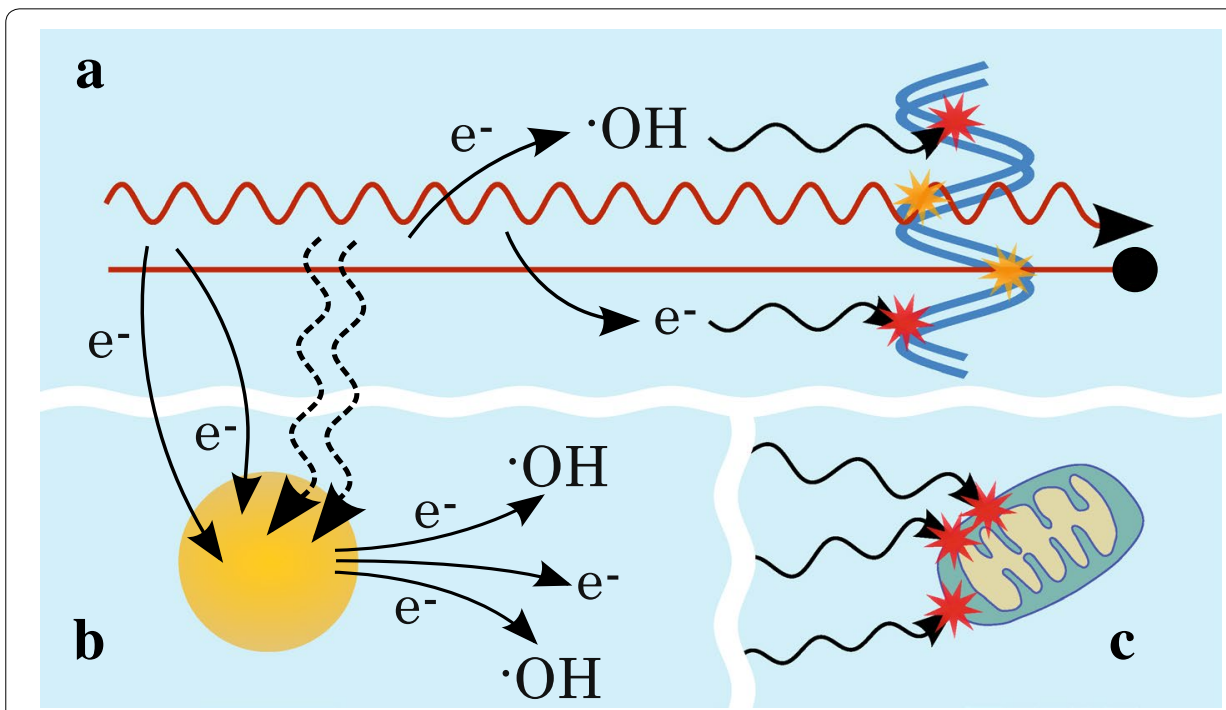

Fig. 2 Illustration of mechanisms of radiation damage in the presence of nanoparticles. In addition to the direct and indirect damage (yellow and red stars, respectively) to DNA or other parts of the cell (a), the incident radiation may also interact with NPs (b) (illustrated by dashed, wiggly arrows) and induce the emission of secondary electrons which can then react with the medium to increase the production of radicals and other reactive species (like $\cdot \mathrm{OH}$ radicals); secondary electrons produced by the radiation or by NPs may also induce further electron emission from NPs. c All the secondary species may diffuse and damage other parts of the cell (like mitochondria). See text for further details 
One of the proposed reasons for the observed radiosensitisation of NPs under photon irradiation is their higher interaction cross section with the radiation up until the megavoltage range compared to that of the water and soft tissue of the cells which contributes to the localisation of the dose. Due to the photoelectric effect scaling proportionally to $(Z / E)^{3}$, where $Z$ is the atomic number and $E$ is the energy of the incoming photon, Auger emission is especially likely to take place for high-Z metals like gold, gadolinium, platinum, or silver (Kobayashi et al. 2010; Porcel et al. 2010; Coulter et al. 2013; Schlathölter et al. 2016), which have been shown to produce a larger number of Auger electrons when compared to the relatively light elements of biological tissue such as hydrogen, carbon, and oxygen. The increase in the interaction cross section of gold vs. soft tissue decreases at high energies, and it has indeed been found that the energy of the radiation plays a major role in the radiosensitisation effect. Rahman et al. found that low energy X-rays of $80 \mathrm{kVp}$ (peak kilovoltage), in combination with AuNPs were able to deliver a high DEF and that the effect increased with increasing concentration of AuNPs. DEF values of 4, 20 , and 24.6 were found for concentrations of $0.25,0.5$, and $1 \mathrm{mM}$, respectively. Furthermore, at $150 \mathrm{kVp}$ X-ray, the DEF increased from 1.4 to 2.2 for 0.5 and $1 \mathrm{mM}$ AuNPs, respectively (Rahman et al. 2009).

In the clinical context, radiotherapy is often delivered using MeV X-rays, since $\mathrm{keV}$ photons have less penetration in tissue and would only be able to treat superficial tumours (Rahman et al. 2009). Despite the much lower interaction cross section at these energies, experiments show a radiosensitisation effect nonetheless (Butterworth et al. 2013). McMahon et al. (2011) showed computationally that the radiosensitisation seen with photons in these energies is caused by the interaction of NPs with secondary species produced by ionisation of the water medium rather than with the radiation itself.

Particularly efficient for cell killing is the induction of "complex damage" due to the difficulty in successfully repairing such damage (as described above). For example, Porcel et al. showed an increase in the DSB/SSB ratio in plasmid DNA when using platinum NPs with ion radiation (Porcel et al. 2010), and increased amount of strand breaks was also observed by Xiao et al. (2011) who used AuNPs irradiated by electrons.

The local effect model (LEM) was used by Lin et al. (2015) to simulate the effect of AuNPs under X-ray and proton radiation on cell killing. Their study showed that the uptake of NPs into cells is crucial for proton therapy but less so for photon therapy where AuNPs located in the intercellular medium can generate radicals that migrate and contribute to DNA damage. It should be mentioned that the simulation only included DNA damage, which may not be the only target in the cell and furthermore, it accounted only for direct interaction between the radiation and the NPs, thus excluding the interaction between NPs and secondary species, as described above.

However, it should be noted that although producing DNA strand breaks is an important factor in inducing cell death and most experiments monitor the increase in SSBs and DSBs, it is by no means the only target in cancer cells for nanoparticle radiosensitisation (Kobayashi et al. 2010; Štefancikova 2014; McQuaid et al. 2016).

Another potential target is the mitochondria, as disruption of their membrane potential can lead to apoptosis. AuNPs have been found to induce oxidation of the mitochondrial membrane protein cardiolipin and also the disruption of mitochondrial membrane potential. Depolarisation of the membrane potential may be due to increased radical 
production promoted by NPs themselves, and oxidation of cardiolipin causes the release cytochrome c. Both processes can trigger apoptosis and thus contribute to enhanced radiosensitisation (Taggart et al. 2014, 2016).

\section{Nanoparticles with ion radiation}

In addition to the interaction between NPs and the secondary electrons produced by the ionisation of the medium by the ion radiation, it was recently shown in a theoretical study that metal NPs in combination with ion radiation significantly increase the secondary electron yield, compared to that of pure water, due to excitation of plasmons in the NP Verkhovtsev et al. (2015a, b).

Plasmons are the excitations of delocalised electrons of the material and can be efficiently excited especially in metals. Verkhovtsev et al. showed that an order of magnitude increased the production of low energy electrons from metal NPs, compared to a similar volume of water, as the result of collective electronic excitation in the NP Verkhovtsev et al. (2015a, b). Specifically, it was shown that noble metal NPs are superior to, for example, gadolinium NPs because of the energy of the surface plasmon, which in noble metals is higher than the ionisation potential, such that the relaxation of plasmon excitations can cause the emission of an electron.

The effect of collective excitation was also shown for carbon-based NPs, although the effect is not as strong as for other metal systems like gold or platinum (Verkhovtsev et al. 2015c). Due to the fact that the plasmon resonance energy for carbon NPs occurs at higher energies than for NPs of noble metals, it was proposed that NPs made of a combination of materials with different plasmon resonance energies will be able to exploit a larger spectrum of ion energies, leading to a more efficient electron production from such NPs.

\section{Physico-chemical properties of NPs and their role in radiosensitisation}

There are several aspects to consider when developing new NPs such as the material they should be constructed from, their shape and size, the surface coating, and the net charge on the NP. ${ }^{1}$ All of these parameters influence cellular uptake and the biological response of cells as well as their interaction with radiation. Finding the optimal design is a non-trivial problem due to the large number of tuneable parameters. Here, we will overview some of the key parameters.

\section{Size}

The size of NPs used for radiosensitisation affects both how they interact with the biological system and how they interact with the radiation.

The biodistribution and route of elimination from the body are strongly depending on the size of the NPs. To avoid accumulation of NPs in organs such as heart and liver, causing potential long-term side effects, metal NPs should be eliminated from the body within a few days, which will still provide a window for radiotherapy with NPs present. This is best achieved through renal clearance which is dependent on the size of

${ }^{1}$ Changed "Parameters of" to "Physico-chemical properties of" since this was requested by the reviewer for the paragraph in the introduction, and so to keep it the same. 
the NPs (Alric et al. 2013; Barreto et al. 2011; Sancey et al. 2014). NPs with a hydrodynamic diameter greater than $10 \mathrm{~nm}$ are more likely to be captured by the liver, whereas NPs smaller than $6 \mathrm{~nm}$ are usually eliminated by renal clearance independently of their charge (Longmire et al. 2008; Bertrand and Leroux 2012; Moghimi et al. 2012; Alexis et al. 2008; Almeida et al. 2011; Albanese et al. 2012; Owens and Peppas 2006; Choi et al. 2007). NPs between 6 and $10 \mathrm{~nm}$ can also be eliminated via renal clearance, although in this case, positively charged NPs are eliminated faster than negative or neutral NPs (Longmire et al. 2008).

Although current data point to a maximum cell uptake by NPs between 20 and $60 \mathrm{~nm}$ (Albanese et al. 2012; Chithrani et al. 2006; Zhang et al. 2009; Perrault et al. 2009), smaller NPs still accumulate in tumours due to the enhanced permeability and retention effect (EPR) (Sancey et al. 2014). Smaller NPs will also tend to diffuse further into tumour tissue from the bloodstream, and therefore present a more even distribution in larger tumours than larger NPs. This may counteract the lower active uptake and the faster elimination from the blood stream of small NPs (Albanese et al. 2012; Perrault et al. 2009).

Regarding toxicity of AuNPs, some studies have concluded that toxicity is minimal for NPs below $5 \mathrm{~nm}$ and above $50 \mathrm{~nm}$, but severe at intermediate sizes (Akhter et al. 2012). Other studies have shown toxicity for AuNPs of diameter 3, 8, and $30 \mathrm{~nm}$, but not for 5, 6, 10, 17, or $48 \mathrm{~nm}$ (Vijayakumar and Ganesan 2013). This is clearly a complex question, and further research is necessary to define mechanisms of toxicity of AuNPs.

When considering the interaction between NPs and radiation, the size of the NPs is also important. As AuNPs become larger, more of the ionising events from interaction with secondary electrons and radiation occur in the bulk of the NPs, reducing the dose deposited in the medium around the NP (McMahon et al. 2011). Carter et al. (2007) found that the production of low energy electrons was increased for $3 \mathrm{~nm}$ NPs compared with $6 \mathrm{~nm}$ NPs, and Lin et al. (2015) found improved cell killing in their theoretical study for $2 \mathrm{~nm}$ AuNPs compared to sizes up to $50 \mathrm{~nm}$ because secondary electrons formed in larger NPs have a higher probability of dissipating their energy inside the NP before reaching the surface.

\section{Surface charge}

A positive charge on the surface of NPs is thought to improve the uptake into cells due to its interaction with the negatively charged lipid membrane (Beddoes et al. 2015; Albanese et al. 2012; Yah 2013; Hirsch et al. 2013; Kalay et al. 2014). Positively charged NPs could also selectively target cancer cells because of the glycocalyx structure, which, besides often being larger, can be more negatively charged on some cancer cells (Stylianopoulos et al. 2013; Sarin 2010). This glycocalyx is composed of different glycoproteins, and glycosaminoglycans, which can influence the membrane organisation, signal transduction, and possibly enhance endocytosis (Paszek et al. 2014).

Although the amount of charge on NPs is linked to the cell membrane penetration, the exact optimal amount of charge is unknown (Beddoes et al. 2015). Da Rocha et al. (2013) showed computationally that the uptake pathway is dependent on the amount of charge and for neutral or slightly cationic NPs, a passive membrane translocation was favoured, whereas for highly cationic NPs, an endocytosis-mediated uptake was dominant. Due to 
the more pronounced interaction, positively charged NPs induce higher local distortion of the membrane and can perturb the transmembrane potential thereby interfering with certain cell functions, such as ion transport, and increase the probability of pore formation in the membrane (Beddoes et al. 2015; Albanese et al. 2012).

When a foreign object is introduced to the bloodstream, specialised serum proteins called opsonins will adsorb onto the surface of the object, labelling it for clearance from the body (Malam et al. 2009). Since these proteins have a negative charge, positively charged NPs will tend to be eliminated faster in vivo compared to neutral or negatively charged NPs (Alric et al. 2013; Alexis et al. 2008). This can be circumvented by appropriately coating the NP, as will be discussed below.

\section{Concentration of NPs}

It was recognised by Hainfield et al. (2004) in some of the earliest studies of NPs as a radiotherapy agent, that the concentration of NPs in tumour tissue plays an important role in the radiosensitisation effects, and it has since been reported that the concentration of AuNPs plays a larger role in radiation dose enhancement than their size (Mesbahi et al. 2013; Babaei and Ganjalikhani 2014). Brun et al. investigated the relationship between plasmid DNA:AuNP ratio, incident X-ray energy, and AuNP size (Brun et al. 2009). Across a range of DNA:AuNP ratios between 1:1 and 1:10, photon energies from 14.8 to $70 \mathrm{keV}$, and sizes in the range of $8-92 \mathrm{~nm}$, they found that the best radioenhancement (sixfold improvement relative to the controls) was achieved with $37.5 \mathrm{~nm}$ AuNPs, at ratio of 1:1 DNA:AuNP, and an energy of $50 \mathrm{keV}$ (Brun et al. 2009).

\section{Coating of nanoparticles}

Coating of NPs can to help control the interaction of NPs with the proteins of the bloodstream (Monopoli et al. 2011, 2012; Krpetić et al. 2014). Additionally, NP coating can be used to target specifically the tumour cells in the body (see "Active targeting" section and references therein). The targeting strategies that are being employed in order to ensure a sufficient concentration of NPs in tumour cells can be divided into two categories: passive targeting and active targeting (Akhter et al. 2012). In passive targeting, one takes advantage of the higher endocytic uptake of cancer cells and leaky vasculature around tumours which allow for higher uptake of NPs than in healthy tissues (Barreto et al. 2011), while in active targeting, the NPs are functionalised with specific molecules that interact with receptors known to be selectively present in tumour cells (Salvati et al. 2013).

The applied coating also allows for controlling of the charge of the surface of the NPs. In addition to the interactions with opsonin proteins, that were already mentioned, the surface charge plays a role in the stability of AuNPs (for example, their tendency to aggregate) in aqueous solution and in the body (Alkilany and Murphy 2010). Coating of NPs can therefore provide partial control of life time and uptake dynamics of the AuNPs (Chithrani et al. 2009; Thierry and Griesser 2012; Saptarshi et al. 2013; Krpetić et al. 2011). One concern, however, when applying coating to NPs intended for radiosensitising agents is that the coating may absorb secondary electrons emitted from the metal core. Although radiosensitisation has been shown for coated AuNPs (Liu et al. 2010; Zhang et al. 2012), the coating may reduce the amount of radicals produced in the process, as recently shown by Gilles et al. (2014). 


\section{Passive targeting}

When the organism recognises a foreign body in the bloodstream, specialised serum proteins called opsonins will adsorb on the surface of the body labelling it for clearance from the body (Malam et al. 2009). It has been shown that this can be prevented by attaching appropriate molecules on the surface of the NPs, for example poly(ethylene glycol) (PEG) (Alexis et al. 2008; Otsuka et al. 2003; Illés et al. 2014) (see Fig. 3 for an illustration of a PEG-coated AuNP). It is thought that PEG-coating of NPs provides a repelling force on the opsonins thus unlabelling them to cover their surface (Thierry and Griesser 2012; Otsuka et al. 2003). Since NPs tend to concentrate in tumour tissue as a consequence of abnormal blood vessel wall formation around tumour tissue and poorly developed lymphatic system that limits drainage of macromolecules from tumour tissue (Ranganathan et al. 2012), the enhanced permeability and retention effect (EPR) is observed in this case. Increasing the blood circulation time by coating with e.g. PEG thus leads to higher passive uptake due to the EPR effect. The ability of the coating layer to provide the passive targeting conditions depends on several factors, like the size of the NP core or the length and surface density of capping molecules and have been already investigated both computationally and experimentally (Otsuka et al. 2003; Walkey et al. 2012; Kingshott et al. 2002; Haume et al. 2016; Lee et al. 2009).

\section{Active targeting}

Active targeting involves attaching to the surface of NPs other molecules that have specific affinities to interact with cancer tissues. The main motivation is to avoid relying on passive uptake through the EPR effect (Coulter et al. 2013). This has been achieved, for example, with antibodies (Shmeeda et al. 2009), peptides (Chanda et al. 2010; Kumar et al. 2012), folates (Samadian et al. 2016; Zwicke et al. 2012), aptamers (Li et al. 2015; Wu et al. 2015), hormones (Dreaden et al. 2009, 2012), and glucose molecules (Calvaresi and Hergenrother 2013; Gromnicova et al. 2013; Hu et al. 2015).

\section{Combination targeting}

It is possible to combine the two abovementioned targeting strategies. To utilise PEG for increased circulation time, the ratio of PEG to targeting ligand has to be optimised. An excess of targeting ligand will lead to reduced circulation time (Shmeeda et al. 2009), whereas an excess of PEG will dilute the effect of the active targeting groups. Dai et al.
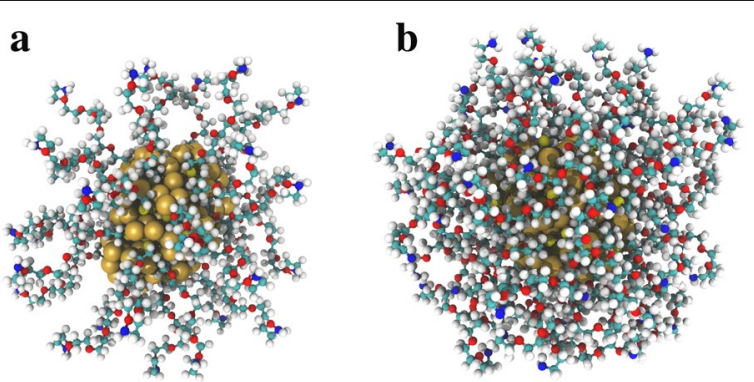

Fig. 3 Illustration of PEG-coated AuNPs. Output from simulation of $1.4 \mathrm{~nm}$ AuNPs coated with a 32 and $\mathbf{b} 60$ PEG molecules. Details in Ref. Haume et al. (2016) 
found that for combination coatings, the length of PEG molecules should not exceed the length of the targeting ligands in order to prevent PEG molecules blocking the receptorligand interaction (Dai et al. 2014).

\section{Gold nanoparticle toxicity}

Despite the various advantages of AuNPs, they are relatively expensive and even if AuNPs are reported to be inert and biocompatible, more information about their toxicological profile still needs to be provided (Kwatra et al. 2013). As mentioned above, NPs below $5 \mathrm{~nm}$ are often used for radiosensitisation purposes due to the relatively rapid elimination from the body, good uptake, and favourable interaction with radiation, but at these sizes AuNPs can become chemically reactive (Alkilany and Murphy 2010; Ionita et al. 2007; Zhang et al. 2003; Pan et al. 2009; Xia et al. 2006).

Previous work has focused on the potential toxicity of AuNPs. Tables 1 and 2 form a non-exhaustive list of the different toxicology studies conducted with differently sized AuNPs, various cell types, and using ranges of AuNPs concentrations. This toxicity can be measured on in vitro models, using different measurements. The most common one is the measure of the half maximal inhibitory concentration $\left(\mathrm{IC}_{50}\right)$, the concentration of chemicals which gives a decrease of $50 \%$ of the cell viability.

From the tables, it can be concluded that the toxic potential of AuNPs varies depending on their size and applied coating. Moreover, the toxic potential can also differ for various cell types. Pan et al. (2007) showed that the toxicity of coated AuNPs is sizedependent but does not depend on the type of coating as, for example, sodium triphenylphosphine monosulfonate (TPPMS) and sodium triphenylphosphine trisulfonate (TPPTS) coatings have the same toxicity for different cell lines.

However, Tsoli et al. (2005) found 50\% toxicity after exposure to $0.24 \mu \mathrm{M}$ of $1.4 \mathrm{~nm}$ AuNPs for $24 \mathrm{~h}$. They found that AuNPs can improve the toxicity for cancer cell as compared to standard chemotherapy. For example, the $\mathrm{IC}_{50}$ on a melanoma cell line exposed to $1.4 \mathrm{~nm}$ AuNPs was 180 times lower than the $\mathrm{IC}_{50}$ after exposure to cisplatin (Tsoli et al. 2005).

Furthermore, altered gene expression has also been observed due to the presence of NPs causing phenotypic changes (Ng et al. 2015) and cytokine induction (Fujiwara et al. 2015). NPs may also have a role in propagating the bystander effect (Thubagere and Reinhard 2010). The bystander mechanism is observed when non-irradiated cells behave as if they were irradiated due to signals received from their irradiated neighbours. This effect is mainly propagated through reactive nitrogen and oxygen species, oxidised DNA from apoptotic cells, and cytokine production and release (Havaki et al. 2015). Since NPs seem to interfere with these mechanisms it is possible that they could potentially propagate bystander signalling. Thus determining the way NPs interact and modulate cell response could give further insights towards targeting specifically cancer cells and improving therapeutic outcomes.

\section{Future challenges and outlook}

Even though photon radiotherapy is the most common treatment for a number of cancers with high effectiveness, it can still be optimised in order to reduce the side effects and increase the survival of healthy tissue. 
Table 1 In vitro toxicology studies of cancer models to AuNP exposure for AuNPs smaller than $4 \mathrm{~nm}$

\begin{tabular}{|c|c|c|c|c|c|c|}
\hline Size $(\mathrm{nm})$ & Coating & Cancer cell line & Exposure & Time (h) & Toxicity & Ref. \\
\hline \multirow[t]{4}{*}{2} & MMPC1 & \multirow[t]{2}{*}{$\cos -1$} & \multirow[t]{2}{*}{$0.38-3 \mu \mathrm{M}$} & \multirow[t]{4}{*}{$1-24$} & $\mathrm{IC}_{50}=1.0 \mu \mathrm{M}$ & \multirow{4}{*}{$\begin{array}{l}\text { Goodman et al. } \\
(2004)\end{array}$} \\
\hline & MMPC2 & & & & $\mathrm{IC}_{50}>7.37 \mu \mathrm{M}$ & \\
\hline & MMPC1 & \multirow[t]{2}{*}{ Red blood cells } & \multirow[t]{2}{*}{$0.27-833 \mu \mathrm{M}$} & & $\mathrm{IC}_{50}=1.1 \mu \mathrm{M}$ & \\
\hline & MMPC2 & & & & $I_{50}=72 \mu \mathrm{M}$ & \\
\hline $3.5 \pm 0.7$ & $\begin{array}{l}\text { Lysine, } \\
\text { poly(lysine) }\end{array}$ & $\begin{array}{l}\text { RAW } 264.7 \\
\text { mouse mac- } \\
\text { rophage }\end{array}$ & $10-100 \mu \mathrm{M}$ & $24-72$ & $\begin{array}{l}>100 \mu \mathrm{M} \text { after } \\
24 \mathrm{~h}\end{array}$ & $\begin{array}{l}\text { Shukla et al. } \\
(2005)\end{array}$ \\
\hline \multirow[t]{2}{*}{1.4} & \multirow[t]{2}{*}{$\mathrm{PH}_{2} \mathrm{PC}_{6} \mathrm{H}_{4} \mathrm{SO}_{3} \mathrm{H}$} & MV3, & \multirow[t]{2}{*}{$<0.4 \mathrm{mM}$} & \multirow[t]{2}{*}{24} & $\mathrm{IC}_{50}=0.24 \mu \mathrm{M}$ & \multirow[t]{2}{*}{ Tsoli et al. (2005) } \\
\hline & & BLM & & & $\mathrm{IC}_{50}=0.30 \mu \mathrm{M}$ & \\
\hline 1.1 & GSH & HeLa & $5.6 \mathrm{mM}$ & 48 & $\mathrm{IC}_{50}=3130 \mu \mathrm{M}$ & Pan et al. (2009) \\
\hline \multirow[t]{2}{*}{1.4} & TPPMS & & & & $\mathrm{IC}_{50}=48 \mu \mathrm{M}$ & \\
\hline & TPPMS, GSH & & & & $\mathrm{IC}_{50}=181 \mu \mathrm{M}$ & \\
\hline \multirow[t]{4}{*}{1.4} & \multirow[t]{3}{*}{ TPPMS } & \multirow{3}{*}{$\begin{array}{l}\text { HeLa } \\
\text { SK-mel-28 }\end{array}$} & \multirow[t]{3}{*}{ Up to $10 \mathrm{mM}$} & \multirow[t]{4}{*}{36} & $\mathrm{IC}_{50}=30 \mu \mathrm{M}$ & \multirow[t]{4}{*}{ Pan et al. (2007) } \\
\hline & & & & & $\begin{array}{l}J 774 \mathrm{~A} 1 \\
\quad \mathrm{C}_{50}=30 \mu \mathrm{M}\end{array}$ & \\
\hline & & & & & 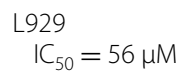 & \\
\hline & TPPTS & HeLa & & & $I C_{50}=46 \mu \mathrm{M}$ & \\
\hline 1.9 & & BAECS & $0.125-1 \mathrm{mM}$ & & $\begin{array}{l}\text { 30\% cell } \\
\text { death at } 1 \\
\text { mM AuNPs } \\
\text { exposure }\end{array}$ & $\begin{array}{l}\text { Rahman et al. } \\
\text { (2009) }\end{array}$ \\
\hline \multirow[t]{3}{*}{1.9} & & Du-145 & \multirow[t]{3}{*}{ Up to $2 \mathrm{mg} / \mathrm{ml}$} & \multirow[t]{3}{*}{24} & $\mathrm{LD}_{50}=20 \mu \mathrm{M}$ & \multirow{3}{*}{$\begin{array}{l}\text { Coulter et al. } \\
\text { (2012) }\end{array}$} \\
\hline & & MDA-MB-231 & & & $\mathrm{LD}_{50}=24.6 \mu \mathrm{M}$ & \\
\hline & & L132 & & & $\mathrm{LD}_{50}=320 \mu \mathrm{M}$ & \\
\hline
\end{tabular}

MMPC1 and MMPC2 mixed monolayer gold clusters functionalised with quarternary ammonium and with carboxylic acid, respectively, TPPMS sodium triphenylphosphine monosulfonate, TPPTS sodium triphenylphosphine trisulfonate, PEG polyethylene glycol, GHS glutathione

Table 2 In vitro toxicology studies of cancer models to AuNP exposure for AuNPs larger than $4 \mathrm{~nm}$

\begin{tabular}{|c|c|c|c|c|c|c|c|}
\hline \multirow{2}{*}{$\frac{\text { Size }(\mathbf{n m})}{4,12,18}$} & \multirow{2}{*}{$\begin{array}{l}\text { Coating } \\
\text { CTAB, citrate, } \\
\text { cysteine, } \\
\text { glucose, } \\
\text { biotin }\end{array}$} & \multicolumn{2}{|c|}{ Cancer cell line } & \multirow{2}{*}{$\begin{array}{l}\text { Exposure } \\
1-250 \mathrm{nM}\end{array}$} & \multirow{2}{*}{$\begin{array}{l}\text { Time (h) } \\
72\end{array}$} & \multirow{2}{*}{$\begin{array}{l}\text { Toxicity } \\
>25 \mu \mathrm{M}\end{array}$} & \multirow{2}{*}{$\begin{array}{l}\text { Ref. } \\
\begin{array}{c}\text { Connor et al. } \\
(2005)\end{array}\end{array}$} \\
\hline & & $\begin{array}{l}\text { K562 leukae- } \\
\text { mia }\end{array}$ & Human & & & & \\
\hline 4.8 & \multirow[t]{4}{*}{ PEG } & \multirow{4}{*}{\multicolumn{2}{|c|}{ HeLa }} & \multirow[t]{4}{*}{$1-250 \mu \mathrm{M}$} & \multirow[t]{4}{*}{48} & $\mathrm{IC}_{50}=0.205 \mathrm{mM}$ & \multirow{4}{*}{$\begin{array}{l}\text { Zhang et al. } \\
\text { (2012) }\end{array}$} \\
\hline 12.1 & & & & & & $\mathrm{IC}_{50}=0.477 \mathrm{mM}$ & \\
\hline 27.3 & & & & & & $\mathrm{IC}_{50}=0.448 \mathrm{mM}$ & \\
\hline 46.4 & & & & & & $\mathrm{IC}_{50}=0.613 \mathrm{mM}$ & \\
\hline \multirow[t]{2}{*}{33} & \multirow[t]{2}{*}{$\mathrm{CTAB}$, citrate } & A549 & & \multirow[t]{2}{*}{$0-120 \mathrm{nM}$} & \multirow[t]{2}{*}{48} & $\mathrm{IC}_{50} \approx 100 \mathrm{nM}$ & \multirow{2}{*}{$\begin{array}{l}\text { Patra et al. } \\
(2007)\end{array}$} \\
\hline & & BHK21 & & & & $\begin{array}{l}\text { No toxicity } \\
\text { observed for } \\
\text { BHK21 up to } \\
\text { these concen- } \\
\text { trations }\end{array}$ & \\
\hline \multirow[t]{2}{*}{$35.6 \pm 6.7$} & \multirow{2}{*}{$\begin{array}{r}\text { Cetuximab } \\
\text { antibody }\end{array}$} & Panc-1 & & \multirow[t]{2}{*}{$100 \mathrm{nM}$} & & $\mathrm{IC}_{50} \approx 100 \mathrm{nM}$ & \multirow{2}{*}{$\begin{array}{l}\text { Glazer et al. } \\
(2010)\end{array}$} \\
\hline & & Cama-1 & & & & NA & \\
\hline
\end{tabular}

CTAB cetyltrimethylammonium bromide, $P E G$ polyethylene glycol 
It has already been shown that introducing various radiosensitisers may help to achieve this goal, and among others, NPs present a high potential for various modes of action in the cancerous cells. Nonetheless, although increasing radiotherapy efficacy using nanoparticles could potentially improve this survival rate in the clinic context, in this still-developing field there are many unknowns in the mechanisms of action both at the molecular and cellular level, as well as when considering their potential impact on cellular communication.

Increased radical production has been attributed to the presence of NPs even in the absence of radiation which can cause damage to the cellular components due to ROS being generated (Pan et al. 2009) triggering first the apoptosis and as a consequence the necrosis of the cell (Xia et al. 2006). Although numerous studies on the size, shape, and capping agent of NPs have been performed, it is still not clear what are the optimal conditions for the highest targeting rate of cancerous cells; thus much more work in this field is required.

From the very basic knowledge of photoelectric and related effects it can be easily concluded, that there are clearly benefits in combining AuNPs with radiotherapy. Here likewise much work is still necessary in order to optimise not only the multi-parameter properties mentioned above, but also to predict the most efficient way in secondaries production. It was already shown that the surface modifications, which increase the cellular uptake and make the passive or active targeting possible, may cap the secondary electrons in the close vicinity of the NP, thus preventing an efficient radiosensitisation. This implies that some new compromises between what has been known to work and the aimed actions must be explored.

There is a great amount of both experimental and theoretical work devoted to all possible parameters of NPs. Such great variability of sizes, shapes, and coatings associated with the differential cellular responses dependent on cancer types makes it at the moment difficult to establish any correlations or standard conditions for treatments; therefore, some clarification and organisation of the achievements of various communities must be done.

\begin{abstract}
Abbreviations
AuNP: gold nanoparticle; CTAB: cetyltrimethylammonium bromide; DEF: dose enhancement factor; DSB: double strand break; EPR: enhanced permeability and retention; GHS: glutathione; $I C_{50}$ : half maximal inhibitory concentration; LEM: local effect model; LET: linear energy transfer; MMPC1: mixed monolayer gold clusters functionalised with quarternary ammonium; MMPC2: mixed monolayer gold clusters functionalised with carboxylic acid; NP: nanoparticle; PEG: polyethylene glycol; SOBP: spread-out-Bragg-peak; SSB: single strand break; TPPMS: sodium triphenylphosphine monosulfonate; TPPTS: sodium triphenylphosphine trisulfonate.
\end{abstract}

\title{
Authors' contributions
}

$\mathrm{KH}$, SR, and SG wrote the paper, and MAS, KTB, AVS, KMP, JG, and NJM supervised the work and provided corrections and discussions. All authors read and approved the final manusrcipt.

\section{Author details}

${ }^{1}$ Department of Physical Sciences, The Open University, Walton Hall, Milton Keynes MK7 6AA, UK. ${ }^{2}$ School of Medicine, Dentistry and Biomedical Sciences, Queen's University Belfast, Lisburn Road, Belfast BT9 7BL, UK. ${ }^{3}$ Department of Life, Health and Chemical Sciences, The Open University, Walton Hall, Milton Keynes MK7 6AA, UK. ${ }^{2}$ Department of Control and Power Engineering, Faculty of Ocean Engineering and Ship Technology, Gdansk University of Technology, 80-233 Gdansk, Poland. ${ }^{5}$ MBN Research Center, Altenhöferallee 3, 60438 Frankfurt, Germany. 


\section{Competing interests}

The authors declare that they have no competing interests.

\section{Funding}

This work was supported by the European Union Seventh Framework Programme [PEOPLE-2013-ITN-ARGENT project] under Grant Agreement No. 608163.

Received: 6 June 2016 Accepted: 14 October 2016

Published online: 03 November 2016

\section{References}

Akhter S, Ahmad MZ, Ahmad FJ, Storm G, Kok RJ. Gold nanoparticles in theranostic oncology: current state-of-the-art. Exp Opin Drug Deliv. 2012;9(10):1225-43. doi:10.1517/17425247.2012.716824.

Albanese A, Tang PS, Chan WCW. The effect of nanoparticle size, shape, and surface chemistry on biological systems. Annu Rev Biomed Eng. 2012;14(1):1-16. doi:10.1146/annurev-bioeng-071811-150124.

Alexis F, Pridgen E, Molnar LK, Farokhzad OC. Factors affecting the clearance and biodistribution of polymeric nanoparticles. Mol Pharm. 2008;5(4):505-15. doi:10.1021/mp800051m.

Alkilany AM, Murphy CJ. Toxicity and cellular uptake of gold nanoparticles: what we have learned so far? J Nanoparticle Res. 2010:12(7):2313-33. doi:10.1007/s11051-010-9911-8.

Almeida JPM, Chen AL, Foster A, Drezek R. In vivo biodistribution of nanoparticles. Nanomedicine. 2011;6(5):815-35.

Alric C, Miladi I, Kryza D, Taleb J, Lux F, Bazzi R, Billotey C, Janier M, Perriat P, Roux S, Tillement O. The biodistribution of gold nanoparticles designed for renal clearance. Nanoscale. 2013;5(13):5930-9. doi:10.1039/c3nr00012e.

Babaei M, Ganjalikhani M. The potential effectiveness of nanoparticles as radio sensitizers for radiotherapy. Biolmpacts. 2014;4(1):15-20. doi:10.5681/bi.2014.003

Barreto JA, O'Malley W, Kubeil M, Graham B, Stephan H, Spiccia L. Nanomaterials: applications in cancer imaging and therapy. Adv Mater. 2011;23(12):18-40. doi:10.1002/adma.201100140.

Beddoes CM, Case CP, Briscoe WH. Understanding nanoparticle cellular entry: a physicochemical perspective. Adv Colloid Interface Sci. 2015;218:48-68. doi:10.1016/j.cis.2015.01.007.

Bertrand N, Leroux J-C. The journey of a drug-carrier in the body: an anatomo-physiological perspective. J Controll Release. 2012;161(2):152-63.

Brun E, Sanche L, Sicard-Roselli C. Parameters governing gold nanoparticle X-ray radiosensitization of DNA in solution. Colloids Surf B Biointerfaces. 2009;72(1):128-34. doi:10.1016/j.colsurfb.2009.03.025.

Butterworth KT, McMahon SJ, Currell FJ, Prise KM. Physical basis and biological mechanisms of gold nanoparticle radiosensitization. Nanoscale. 2012:4(16):4830 doi:10.1039/c2nr31227a.

Butterworth KT, McMahon SJ, Taggart LE, Prise KM. Radiosensitization by gold nanoparticles: effective at megavoltage energies and potential role of oxidative stress. Transl Cancer Res. 2013;2(4):269-79.

Calvaresi EC, Hergenrother PJ. Glucose conjugation for the specific targeting and treatment of cancer. Chem Sci. 2013;4(6):2319-33. doi:10.1039/C3SC22205E. http://arXiv:NIHMS150003.

Carter JD, Cheng NN, Qu Y, Suarez GD, Guo T. Nanoscale energy deposition by X-ray absorbing nanostructures. J Phys Chem B. 2007;111:11622-5. doi:10.1021/jp075253u.

Chanda N, Kan P, Watkinson LD, Shukla R, Zambre A, Carmack TL, Engelbrecht H, Lever JR, Katti K, Fent GM. Radioactive gold nanoparticles in cancer therapy: therapeutic efficacy studies of GA-198AuNP nanoconstruct in prostate tumor-bearing mice. Nanomed Nanotechnol Biol Med. 2010;6(2):201-9. doi:10.1016/j.nano.2009.11.001.

Chithrani BD, Ghazani AA, Chan WCW. Determining the size and shape dependence of gold nanoparticle uptake into mammalian cells. Nano Lett. 2006:6:662-8. doi:10.1021/nl0523960.

Chithrani BD, Stewart J, Allen C, Jaffray DA. Intracellular uptake, transport, and processing of nanostructures in cancer cells. Nanomed Nanotechnol Biol Med. 2009;5(2):118-27. doi:10.1016/.j.nano.2009.01.008.

Choi HS, Liu W, Misra P, Tanaka E, Zimmer JP, Ipe BI, Bawendi MG, Frangioni JV. Renal clearance of quantum dots. Nat Biotechnol. 2007; 25(10):1165-70.

Combs SE, Bohl J, Elsässer T, Weber K-J, Schulz-ertner D, Debus J, Weyrather WK. Radiobiological evaluation and correlation with the local effect model (LEM) of carbon ion radiation therapy and temozolomide in glioblastoma cell lines. Int J Radiat Biol. 2009:85(2):126-36. doi:10.1080/09553000802641151.

Connor EE, Mwamuka J, Gole A, Murphy CJ, Wyatt MD. Gold nanoparticles are taken up by human cells but do not cause acute cytotoxicity. Small. 2005;1(3):325-7.

Coulter JA, Jain S, Butterworth KT, Taggart LE, Dickson GR, McMahon SJ, Hyland WB, Muir MF, Trainor C, Hounsell AR, O'Sullivan JM, Schettino G, Currell FJ, Hirst DG, Prise KM. Cell type-dependent uptake, localization, and cytotoxicity of 1.9 nm gold nanoparticles. Int J Nanomed. 2012;7(1):2673-85. doi:10.2147/JJN.S31751.

Coulter JA, Hyland WB, Nicol J, Currell FJ. Radiosensitising nanoparticles as novel cancer therapeutics—pipe dream or realistic prospect? Clin Oncol. 2013;25(10):593-603. doi:10.1016/j.clon.2013.06.011.

Crawford S. Is it time for a new paradigm for systemic cancer treatment? Lessons from a century of cancer chemotherapy. Front Pharmacol. 2013;4(68):1-18. doi:10.3389/fphar.2013.00068.

da Rocha EL, Caramori GF, Rambo CR. Nanoparticle translocation through a lipid bilayer tuned by surface chemistry. Phys Chem Chem Phys. 2013;15(7):2282-90. doi:10.1039/c2cp44035k.

Dai Q, Walkey C, Chan WC. Polyethylene glycol backfilling mitigates the negative impact of the protein corona on nanoparticle cell targeting. Angew Chem Int Ed Engl. 2014;53(20):5093-6. doi:10.1002/anie.201309464.

Danhier F, Feron O, Préat $\mathrm{V}$. To exploit the tumor microenvironment: passive and active tumor targeting of nanocarriers for anti-cancer drug delivery. J Controll Release. 2010;148(2):135-46. doi:10.1016/j.jconrel.2010.08.027. 
de Vera P, Mason NJ, Currell FJ, Solov'yov AV. Molecular dynamics study of accelerated ion-induced shock waves in biological media. Eur Phys J D. 2016 (in press). doi:10.1140/epjd/e2016-70281-7.

Delaney GP, Barton MB. Evidence-based estimates of the demand for radiotherapy. Clin Oncol. 2015;27(2):70-6. doi:10.1016/j.clon.2014.10.005.

Dendy PP, Heaton B. Physics for diagnostic radiology. Boca Raton: CRC Press; 2011

Dreaden EC, Mwakwari SC, Sodji QH, Oyelere AK, El-Sayed MA. Tamoxifen-poly(ethylene glycol)-thiol gold nanoparticle conjugates: enhanced potency and selective delivery for breast cancer treatment. Bioconjugate Chem. 2009;20(12):2247-53. doi:10.1021/bc9002212.

Dreaden EC, Gryder BE, Austin LA, Tene Defo BA, Hayden SC, Pi M, Quarles LD, Oyelere AK, El-Sayed MA. Antiandrogen gold nanoparticles dual-target and overcome treatment resistance in hormone-insensitive prostate cancer cells. bioconjugate Chemi. 2012;23(8):1507-12. doi:10.1021/bc300158k.

Elsässer T, Krämer M, Scholz M. Accuracy of the local effect model for the prediction of biologic effects of carbon ion beams in vitro and in vivo. Int J Radiat Oncol Biol Phys. 2008;71(3):866-72. doi:10.1016/j.jijobp.2008.02.037.

Elsässer T, Scholz M. Cluster effects within the local effect model. Radiat Res. 2007;167(3):319-29. doi:10.1667/RR0467.1.

Emfietzoglou D, Cucinotta FA, Nikjoo H. A complete dielectric response model for liquid water: a solution of the Bethe ridge problem. Radiat Res. 2005;164(2):202-11. doi:10.1667/RR3399.

Folkard M, Prise KM, Vojnovic B, Davies S, Roper MJ, Michael BD. Measurement of DNA damage by electrons with energies between 25 and $4000 \mathrm{eV}$. Int J Radiat Biol. 1993;64(6):651-8.

Fujiwara R, Luo Y, Sasaki T, Fujii K, Ohmori H, Kuniyasu H. Cancer therapeutic effects of titanium dioxide nanoparticles are associated with oxidative stress and cytokine induction. Pathobiology. 2015;82(6):243-51. doi:10.1159/000439404

Gilles M, Brun E, Sicard-roselli C. Gold nanoparticles functionalization notably decreases radiosensitization through hydroxyl radical production under ionizing radiation. Colloids Surf B Biointerfaces. 2014;123:770-7. doi:10.1016/j. colsurfb.2014.10.028.

Glazer ES, Massey KL, Zhu C, Curley SA. Pancreatic carcinoma cells are susceptible to noninvasive radio frequency fields after treatment with targeted gold nanoparticles. Surgery. 2010;148(2):319-24.

Goodman CM, McCusker CD, Yilmaz T, Rotello VM. Toxicity of gold nanoparticles functionalized with cationic and anionic side chains. Bioconjugate Chem. 2004;15(4):897-900.

Greish K. Enhanced permeability and retention of macromolecular drugs in solid tumors: a royal gate for targeted anticancer nanomedicines. J Drug Target. 2007;15(7-8):457-64. doi:10.1080/10611860701539584.

Gromnicova R, Davies HA, Sreekanthreddy P, Romero IA, Lund T, Roitt IM, Phillips JB, Male DK. Glucose-coated gold nanoparticles transfer across human brain endothelium and enter astrocytes in vitro. PLOS ONE. 2013;8(12):81043. doi:10.1371/journal.pone.0081043.

Haettner E, Iwase H, Schardt D. Experimental fragmentation studies with 12C therapy beams. Radiat Prot Dosim. 2006;122(1-4):485-7. doi:10.1093/rpd/ncl402.

Hainfeld JF, Slatkin DN, Smilowitz HM. The use of gold nanoparticles to enhance radiotherapy in mice. Phys Med Biol. 2004;49(18):309-15. doi:10.1088/0031-9155/49/18/N03.

Hainfeld JF, Dilmanian FA, Slatkin DN, Smilowitz HM. Radiotherapy enhancement with gold nanoparticles. J Pharm Pharmacol. 2008;60(8):977-85. doi:10.1211/jpp.60.8.0005.

Hanahan D, Weinberg RA. Hallmarks of cancer: the next generation. Cell. 2011;144(5):646-74. doi:10.1016/j. cell.2011.02.013.

Haume K, Mason NJ, Solov'yov A. Modeling of nanoparticle coatings for medical applications; 2016. arXiv preprint. arXiv:1604.06679

Havaki S, Kotsinas A, Chronopoulos E, Kletsas D, Georgakilas A, Gorgoulis VG. The role of oxidative DNA damage in radiation induced bystander effect. Cancer Lett. 2015;356(1):43-51. doi:10.1016/j.canlet.2014.01.023.

Hirsch V, Salaklang J, Rothen-Rutishauser B, Petri-Fink A. Influence of serum supplemented cell culture medium on colloidal stability of polymer coated iron oxide and polystyrene nanoparticles with impact on cell interactions in vitro. IEEE Trans Magn. 2013;49(1):402-7.

Hossain M, Su M. Nanoparticle location and material-dependent dose enhancement in X-ray radiation therapy. J Phys Chem C. 2012;116(43):23047-52.

Hu C, Niestroj M, Yuan D, Chang S, Chen J. Treating cancer stem cells and cancer metastasis using glucose-coated gold nanoparticles. Int J Nanomed. 2015;10:2065-77. doi:10.2147/IJN.S72144.

Illés E, Szekeres M, Kupcsik E, Tóth IY, Farkas K, Jedlovszky-Hajdú A, Tombácz E. PEGylation of surfacted magnetite core-shell nanoparticles for biomedical application. Colloids Surf A Physicochem Eng Asp. 2014;460:429-40. doi:10.1016/j.colsurfa.2014.01.043.

Ionita P, Conte M, Gilbert BC, Chechik V. Gold nanoparticle-initiated free radical oxidations and halogen abstractions. Org Biomol Chem. 2007;5(21):3504-9.

Joiner M, van der Kogel A. Basic clinical radiobiology, vol. 4. Boca Raton: CRC Press; 2009. doi:10.1201/b13224.

Kalay S, Blanchet C, Culha M. Linear assembly and 3D networks of peptide modified gold nanoparticles. Turk J Chem. 2014;38(5):686-700.

Kavanagh JN, Redmond KM, Schettino G, Prise KM. DNA double strand break repair: a radiation perspective. Antioxid Redox Signal. 2013;18(18):2458-72.

Kingshott P, Thissen H, Griesser HJ. Effects of cloud-point grafting, chain length, and density of PEG layers on competitive adsorption of ocular proteins. Biomaterials. 2002;23(9):2043-56. doi:10.1016/50142-9612(01)00334-9.

Kobayashi K, Usami N, Porcel E, Lacombe S, Le Sech C. Enhancement of radiation effect by heavy elements. Rev Mutat Res. 2010;704(1-3):123-31. doi:10.1016/j.mrrev.2010.01.002.

Kraft G. The radiobiological and physical basis for radiotherapy with protons and heavier ions. Strahlentherapie und Onkologie. 1990;166(1):10-3.

Krämer M, Jäkel O, Haberer T, Kraft G, Schardt D, Weber U. Treatment planning for heavy-ion radiotherapy: physical beam model and dose optimization. Phys Med Biol. 2000;45(11):3299-317. doi:10.1088/0031-9155/45/11/313.

Krämer M, Durante M. Ion beam transport calculations and treatment plans in particle therapy. Eur Phys J D. 2010;60:195202. doi:10.1140/epjd/e2010-00077-8. 
Krpetić Ž, Anguissola S, Garry D, Kelly PM, Dawson KA. In: Capco GD, Chen Y, editors. Nanomaterials: impact on cells and cell organelles. Dordrecht: Springer; 2014. p. 135-56. doi:10.1007/978-94-017-8739-0

Krpetić Ž, Saleemi S, Prior IA, Sée V, Qureshi R, Brust M. Negotiation of intracellular membrane barriers by TAT-modified gold nanoparticles. ACS Nano. 2011;5(6):5195-201. doi:10.1021/nn201369k.

Kumar A, Ma H, Zhang X, Huang K, Jin S, Liu J, Wei T, Cao W, Zou G, Liang X-J. Gold nanoparticles functionalized with therapeutic and targeted peptides for cancer treatment. Biomaterials. 2012;33(4):1180-9. doi:10.1016/j. biomaterials.2011.10.058.

Kwatra D, Venugopal A, Anant S. Nanoparticles in radiation therapy : a summary of various approaches to enhance radiosensitization in cancer. Transl Cancer Res. 2013;2(4):330-42. doi:10.3978/j.issn.2218-676X.2013.08.06.

Lee H, De Vries AH, Marrink SJ, Pastor RW. A coarse-grained model for polyethylene oxide and polyethylene glycol: conformation and hydrodynamics. J Phys Chem B. 2009;113(40):13186-94. doi:10.1021/jp9058966.

Li C-H, Kuo T-R, Su H-J, Lai W-Y, Yang P-C, Chen J-S, Wang D-Y, Wu Y-C, Chen C-C. Fluorescence-guided probes of aptamertargeted gold nanoparticles with computed tomography imaging accesses for in vivo tumor resection. Sci Rep. 2015;5(October):15675. doi:10.1038/srep15675.

Lin Y, McMahon SJ, Paganetti H, Schuemann J. Biological modeling of gold nanoparticle enhanced radiotherapy for proton therapy. Phys Med Biol. 2015;60(10):4149-68. doi:10.1088/0031-9155/60/10/4149.

Liu C-J, Wang C-H, Chen S-T, Chen H-H, Leng W-H, Chien C-C, Wang C-L, Kempson IM, Hwu Y, Lai T-C, Hsiao M, Yang C-S, Chen Y-J, Margaritondo G. Enhancement of cell radiation sensitivity by pegylated gold nanoparticles. Phys Med Biol. 2010;55:931-45. doi:10.1088/0031-9155/55/4/002.

Longmire M, Choyke PL, Kobayashi H. Clearance properties of nano-sized particles and molecules as imaging agents: consideration and caveats. Nanomedicine. 2008;3(5):703-17. doi:10.2217/17435889.3.5.703.

Malam Y, Loizidou M, Seifalian AM. Liposomes and nanoparticles: nanosized vehicles for drug delivery in cancer. Trend Pharmacol Sci. 2009;30(11):592-9. doi:10.1016/j.tips.2009.08.004.

McMahon SJ, Hyland WB, Muir MF, Coulter JA, Jain S, Butterworth KT, Schettino G, Dickson GR, Hounsell AR, O'Sullivan JM, Prise KM, Hirst DG, Currell FJ. Nanodosimetric effects of gold nanoparticles in megavoltage radiation therapy. Radiother Oncol. 2011;100(3):412-6. doi:10.1016/j.radonc.2011.08.026.

McQuaid HN, Muir MF, Taggart LE, McMahon SJ, Coulter JA, Hyland WB, Jain S, et al. Imaging and radiation effects of gold nanoparticles in tumour cells. Sci Rep 6. 2016. doi:10.1038/srep1944210.1038/srep19442

Mesbahi A, Jamali F, Gharehaghaji N. Effect of photon beam energy, gold nanoparticle size and concentration on the dose enhancement in radiation therapy. Biolmpacts. 2013;3(1):29-35. doi:10.5681/bi.2013.002.

Moghimi SM, Hunter AC, Andresen TL. Factors controlling nanoparticle pharmacokinetics: an integrated analysis and perspective. Annu Rev Pharmacol Toxicol. 2012;52:481-503.

Monopoli MP, Walczyk D, Campbell A, Elia G, Lynch I, Baldelli Bombelli F, Dawson KA. Physical-chemical aspects of protein corona: relevance to in vitro and in vivo biological impacts of nanoparticles. J Am Chem Soc. 2011;133(8):2525-34. doi:10.1021/ja107583h.

Monopoli MP, Åberg C, Salvati A, Dawson KA. Biomolecular coronas provide the biological identity of nanosized materials. Nat Nanotechnol. 2012;7(12):779-86. doi:10.1038/nnano.2012.207.

Muddineti OS, Ghosh B, Biswas S. Current trends in using polymer coated gold nanoparticles for cancer therapy. Int J Pharm. 2015;484(1):252-67.

Ng CT, Yung LYL, Swa HLF, Poh RWY, Gunaratne J, Bay BH. Altered protein expression profile associated with phenotypic changes in lung fibroblasts co-cultured with gold nanoparticle-treated small airway epithelial cells. Biomaterials. 2015;39:31-8. doi:10.1016/j.biomaterials.2014.10.063.

Nikjoo H, O'Neill P, Wilson WE, Goodhead DT. Computational approach for determining the spectrum of DNA damage induced by ionizing radiation. Radiat Res. 2001;156(5):577-83. doi:10.1667/0033-7587(2001)156[0577:CAFDTS]2.0. $\mathrm{CO} ; 2$.

Otsuka H, Nagasaki Y, Kataoka K. PEGylated nanoparticles for biological and pharmaceutical applications. Adv Drug Deliv Rev. 2003;55:403-19. doi:10.1016/S0169-409X(02)00226-0.

Owens DE, Peppas NA. Opsonization, biodistribution, and pharmacokinetics of polymeric nanoparticles. Int J Pharm. 2006;307(1):93-102. doi:10.1016/j.jpharm.2005.10.010.

Pan X, Cloutier P, Hunting D, Sanche L. Dissociative electron attachment to DNA. Phys Rev Lett. 2003;90(May):208102. doi:10.1103/PhysRevLett.90.208102.

Pan Y, Neuss S, Leifert A, Fischler M, Wen F, Simon U, Schmid G, Brandau W, Jahnen-Dechent W. Size-dependent cytotoxicity of gold nanoparticles. Small. 2007;3(11):1941-9.

Pan Y, Leifert A, Ruau D, Neuss S, Bornemann J, Schmid G, Brandau W, Simon U, Jahnen-Dechent W. Gold nanoparticles of diameter $1.4 \mathrm{~nm}$ trigger necrosis by oxidative stress and mitochondrial damage. Small. 2009;5(18):2067-76. doi:10.1002/smll.200900466.

Paszek MJ, DuFort CC, Rossier O, Bainer R, Mouw JK, Godula K, Hudak JE, Lakins JN, Wijekoon AC, Cassereau L. Others: the cancer glycocalyx mechanically primes integrin-mediated growth and survival. Nature. 2014;511(7509):319-25.

Patra HK, Banerjee S, Chaudhuri U, Lahiri P, Dasgupta AK. Cell selective response to gold nanoparticles. Nanomed Nanotechnol Biol Med. 2007;3(2):111-9. doi:10.1016/j.nano.2007.03.005.

Perrault SD, Walkey C, Jennings T, Fischer HC, Chan WCW. Mediating tumor targeting efficiency of nanoparticles through design. Nano Lett. 2009;9(5):1909-15. doi:10.1021/nl900031y.

Polf JC, Bronk LF, Driessen WHP, Arap W, Pasqualini R, Gillin M. Enhanced relative biological effectiveness of proton radiotherapy in tumor cells with internalized gold nanoparticles. Appl Phys Lett. 2011;98(19):193702. doi:10.1063/1.3589914.

Porcel E, Liehn S, Remita H, Usami N, Kobayashi K, Furusawa Y, Le Sech C, Lacombe S. Platinum nanoparticles: a promising material for future cancer therapy? Nanotechnology. 2010;21:085103. doi:10.1088/0957-4484/21/8/085103.

Porcel E, Li S, Usami N, Remita H, Furusawa Y, Kobayashi K, Sech CL, Lacombe S. Nano-sensitization under gamma rays and fast ion radiation. J Phys Conf Ser. 2012;373:012006. doi:10.1088/1742-6596/373/1/012006. 
Porcel E, Tillement O, Lux F, Mowat P, Usami N, Kobayashi K, Furusawa Y, Le Sech C, Li S, Lacombe S. Gadolinium-based nanoparticles to improve the hadrontherapy performances. Nanomed Nanotechnol Biol Med. 2014;10(8):1601-8. doi:10.1016/..nano.2014.05.005.

Rahman WN, Bishara N, Ackerly T, He CF, Jackson P, Wong C, Davidson R, Geso M. Enhancement of radiation effects by gold nanoparticles for superficial radiation therapy. Nanomed Nanotechnol Biol Med. 2009;5(2):136-42.

Ranganathan R, Madanmohan S, Kesavan A, Baskar G, Krishnamoorthy YR, Santosham R, Ponraju D, Rayala SK, Venkatraman G. Nanomedicine: towards development of patient-friendly drug-delivery systems for oncological applications. Int J Nanomed. 2012;7:1043-60. doi:10.2147/IJN.S25182.

Salvati A, Pitek AS, Monopoli MP, Prapainop K, Bombelli FB, Hristov DR, Kelly PM, Åberg C, Mahon E, Dawson KA. Transferrin-functionalized nanoparticles lose their targeting capabilities when a biomolecule corona adsorbs on the surface. Nat Nanotechnol. 2013;8(2):137-43. doi:10.1038/nnano.2012.237.

Samadian H, Hosseini-Nami S, Kamrava SK, Ghaznavi H, Shakeri-Zadeh A. Folate-conjugated gold nanoparticle as a new nanoplatform for targeted cancer therapy. J Cancer Res Clin Oncol. 2016; doi:10.1007/s00432-016-2179-3.

Sancey L, Lux F, Kotb S, Roux S, Dufort S, Bianchi A, Crémillieux Y, Fries P, Coll J-L, Rodriguez-Lafrasse C, Janier M, Dutreix M, Barberi-Heyob M, Boschetti F, Denat F, Louis C, Porcel E, Lacombe S, Le Duc G, Deutsch E, Perfettini J-L, Detappe A, Verry C, Berbeco R, Butterworth KT, McMahon SJ, Prise KM, Perriat P, Tillement O. The use of theranostic gadolinium-based nanoprobes to improve radiotherapy efficacy. Br J Radiol. 2014;87(February):20140134. doi:10.1259/ bjr.20140134.

Sánchez-Santos ME. In: García Gómez-Tejedor G, Fuss CM, editors. Therapeutic applications of ionizing radiations. Dordrecht: Springer; 2012. p. 397-409. doi:10.1007/978-94-007-2564-5_24.

Saptarshi SR, Duschl A, Lopata AL. Interaction of nanoparticles with proteins: relation to bio-reactivity of the nanoparticle. J Nanobiotechnol. 2013;11(1):26. doi:10.1186/1477-3155-11-26.

Sarin H. Physiologic upper limits of pore size of different blood capillary types and another perspective on the dual pore theory of microvascular permeability. J Angiogenes Res. 2010;2(1):14. doi:10.1186/2040-2384-2-14.

Schlathölter T, Eustache P, Porcel E, Salado D, Stefancikova L, Tillement O, Lux F, Mowat P, Biegun AK, Van Goethem MJ, Remita H, Lacombe S. Improving proton therapy by metal-containing nanoparticles: nanoscale insights. Int J Nanomed. 2016;11:1549-56. doi:10.2147/IJN.S99410.

Scifoni E, Surdutovich E, Solov'yov AV. Spectra of secondary electrons generated in water by energetic ions. Phys Rev E. 2010;81(2):021903. doi:10.1103/PhysRevE.81.021903. http://arxiv.org/abs/0911.3855v1.

Shmeeda H, Tzemach D, Mak L, Gabizon A. Her2-targeted pegylated liposomal doxorubicin: retention of targetspecific binding and cytotoxicity after in vivo passage. J Controll Release. 2009;136(2):155-60. doi:10.1016/j. jconrel.2009.02.002.

Shukla R, Bansal V, Chaudhary M, Basu A, Bhonde RR, Sastry M. Biocompatibility of gold nanoparticles and their endocytotic fate inside the cellular compartment: a microscopic overview. Langmuir. 2005;21(23):10644-54.

Śmiałek MA, Jones NC, Hoffmann SV, Mason NJ. Measuring the density of DNA films using ultraviolet-visible interferometry. Phys Rev E. 2013;87(6):060701. doi:10.1103/PhysRevE.87.060701.

Śmiałek MA, Ptasińska S, Gow J, Da Pieve C, Mason NJ. Radiosensitization of DNA in presence of Pt(II)-based compounds. Eur Phys J D. 2014;68(4):85.

Štefancikova L, Porcel E, Eustache P, Li S, Salado D, Marco S, Réfrégiers M, Tillement O, Lux F, Lacombe S. Cell localisation of gadolinium-based nanoparticles and related radiosensitising efficacy in glioblastoma cells. Cancer Nanotechnol. 2014;5(6):1-15.

Stewart BWKP, Wild CP. World cancer report 2014. World; 2015.

Stylianopoulos T, Soteriou K, Fukumura D, Jain RK. Cationic nanoparticles have superior transvascular flux into solid tumors: insights from a mathematical model. Ann Biomed Eng. 2013;41(1):68-77. doi:10.1007/s10439-012-0630-4.

Sun T, Zhang YS, Pang B, Hyun DC, Yang M, Xia Y. Engineered nanoparticles for drug delivery in cancer therapy. Angewandte Chemie. 2014;53(46):12320-64. doi:10.1002/anie.201403036.

Surdutovich E, Yakubovich AV, Solov'yov AV. Biodamage via shock waves initiated by irradiation with ions. Sci Rep. 2013;3:1289. doi:10.1038/srep01289.

Surdutovich E, Solov'yov AV. Shock wave initiated by an ion passing through liquid water. Phys Rev E. 2010;82(5):051915. doi:10.1103/PhysRevE.82.051915.

Surdutovich E, Solov'yov AV. Multiscale approach to the physics of radiation damage with ions. Eur Phys J D. 2014;68(11):353. doi:10.1140/epjd/e2014-50004-0.

Taggart LE, McMahon SJ, Currell FJ, Prise KM, Butterworth KT. The role of mitochondrial function in gold nanoparticle mediated radiosensitisation. Cancer Nanotechnol. 2014;5(1):5.

Taggart LE, McMahon SJ, Butterworth KT, Currell FJ, Schettino G, Prise KM. Protein disulphide isomerase as a target for nanoparticle-mediated sensitisation of cancer cells to radiation. Nanotechnology. 2016;27(21):215101.

Terato H, Tanaka R, Nakaarai Y, Nohara T, Doi Y, I wai S, Hirayama R, Furusawa Y, Ide H. Quantitative analysis of isolated and clustered DNA damage induced by gamma-rays, carbon ion beams, and iron ion beams. J Radiat Res. 2008;49(2):133-46. doi:10.1269/jr.07089.

Thierry B, Griesser HJ. Dense PEG layers for efficient immunotargeting of nanoparticles to cancer cells. J Mater Chem. 2012;22(18):8810. doi:10.1039/c2jm30210a.

Thubagere A, Reinhard BM. Nanoparticle-induced apoptosis propagates through hydrogen-peroxide-mediated bystander killing: insights from a human intestinal epithelium in vitro model. ACS Nano. 2010;4(7):3611-22. doi:10.1021/nn100389a.

Tsoli M, Kuhn H, Brandau W, Esche H, Schmid G. Cellular uptake and toxicity of Au55 clusters. Small. 2005;1 (8-9):841-4.

Tsujii H, Kamada T, Shirai T, Noda K, Tsuji H, Karasawa K. Carbon-ion radiotherapy. Tokyo: Springer; 2014. doi:10.1007/978-4-431-54457-9.

Usami N, Kobayashi K, Hirayama R, Furusawa Y, Porcel E, Lacombe S, Sech CL. Comparison of DNA breaks at entrance channel and Bragg peak induced by fast C6+ ions. J Radiat Res. 2010;51:21-6. doi:10.1269/jr.09035.

Verkhovtsev AV, Korol AV, Solov'yov AV. Electron production by sensitizing gold nanoparticles irradiated by fast ions. J Phys Chem C. 2015a;119(20):11000-13. doi:10.1021/jp511419n. 
Verkhovtsev AV, Korol AV, Solov'yov AV. Revealing the mechanism of the low-energy electron yield enhancement from sensitizing nanoparticles. Phys Rev Lett. 2015b;114(6):063401. doi:10.1103/PhysRevLett.114.063401.

Verkhovtsev AV, McKinnon S, de Vera P, Surdutovich E, Guatelli S, Korol AV, Rosenfeld A, Solov'yov AV. Comparative analysis of the secondary electron yield from carbon nanoparticles and pure water medium. Eur Phys J D. 2015c;69(4):116. doi:10.1140/epjd/e2015-50908-y.

Verkhovtsev A, Surdutovich E, Solov'yov AV. Multiscale approach predictions for biological outcomes in ion-beam cancer therapy. Sci Rep. 2016;6:27654. doi:10.1038/srep27654.

Vijayakumar S, Ganesan S. Size-dependent in vitro cytotoxicity assay of gold nanoparticles. Toxicol Environm Chem. 2013;95(2):277-87. doi:10.1080/02772248.2013.770858.

Walkey CD, Olsen JB, Guo H, Emili A, Chan WCW. Nanoparticle size and surface chemistry determine serum protein adsorption and macrophage uptake. J Am Chem Soc. 2012:134(4):2139-47. doi:10.1021/ja2084338.

Wu X, Chen J, Wu M, Zhao JX. Aptamers: active targeting ligands for cancer diagnosis and therapy. Theranostics. 2015;5(4):322-44. doi:10.7150/thno.10257.

Wyer JA, Butterworth KT, Hirst DG, Latimer CJ, Montenegro EC, Shah MB, Currell FJ. Fragmentation and plasmid strand breaks in pure and gold-doped DNA irradiated by beams of fast hydrogen atoms. Phys Med Biol. 2009;54(15):4705.

Xia T, Kovochich M, Brant J, Hotze M, Sempf J, Oberley T, Sioutas C, Yeh JI, Wiesner MR, Nel AE. Comparison of the abilities of ambient and manufactured nanoparticles to induce cellular toxicity according to an oxidative stress paradigm. Nano Lett. 2006;6(8):1794-807. doi:10.1021/nl061025k.

Xiao F, Zheng Y, Cloutier P, He Y, Hunting D, Sanche L. On the role of low-energy electrons in the radiosensitization of DNA by gold nanoparticles. Nanotechnology. 2011;22:465101. doi:10.1088/0957-4484/22/46/465101.

Yah CS. The toxicity of gold nanoparticles in relation to their physiochemical properties. Biomed Res. 2013;24(3):400-13.

Zhang Z, Berg A, Levanon H, Fessenden RW, Meisel D. On the interactions of free radicals with gold nanoparticles. J Am Chem Soc. 2003;125(26):7959-63.

Zhang SX, Gao J, Buchholz TA, Wang Z, Salehpour MR, Drezek RA, Yu TK. Quantifying tumor-selective radiation dose enhancements using gold nanoparticles: a monte carlo simulation study. Biomed Microdevices. 2009;11(4):92533. doi:10.1007/s10544-009-9309-5.

Zhang S, Li J, Lykotrafitis G, Bao G, Suresh S. Size-dependent endocytosis of nanoparticles. Adv Mater. 2009;21(4):419-24. doi:10.1002/adma.200801393.

Zhang X-D, Wu D, Shen X, Chen J, Sun Y-M, Liu P-X, Liang X-J. Size-dependent radiosensitization of PEG-coated gold nanoparticles for cancer radiation therapy. Biomaterials. 2012;33:6408-19. doi:10.1016/j.biomaterials.2012.05.047.

Zwicke GL, Mansoori GA, Jeffery CJ. Utilizing the folate receptor for active targeting of cancer nanotherapeutics. Nano Rev. 2012;3:1-11. doi:10.3402/nano.v3i0.18496.

\title{
Submit your manuscript to a SpringerOpen ${ }^{\circ}$ journal and benefit from:
}

\author{
Convenient online submission \\ - Rigorous peer review \\ - Immediate publication on acceptance \\ - Open access: articles freely available online \\ - High visibility within the field \\ Retaining the copyright to your article
}

Submit your next manuscript at $\gg$ springeropen.com 